\title{
Antidiabetic activity of Manomani chooranam aqueous extract on female wistar albino rats
}

\author{
Sabari Anandh J. V. ${ }^{1}$, Manimekalai Kumarappan ${ }^{1}$, Padmavathi Shanmuganathan ${ }^{1}$, \\ Subha Vinayagam ${ }^{1}$, Iyyankannu ${ }^{2}$, Uma Narayanamurthy ${ }^{1 *}$
}

\begin{abstract}
${ }^{1}$ Department of Pharmacology, Mahatma Gandhi Medical College and Research Institute, Puducherry, India

${ }^{2}$ Department of Sirappu Maruthuvam, Maria Siddha Medical College, Thiruvattaru, Kanyakumari, India
\end{abstract}

Received: 02 August 2019 Accepted: 03 August 2019

*Correspondence to:

Dr. Uma Narayanamurthy, Email: numa.lally@gmail.com

Copyright: (C) the author(s), publisher and licensee Medip Academy. This is an openaccess article distributed under the terms of the Creative Commons Attribution NonCommercial License, which permits unrestricted noncommercial use, distribution, and reproduction in any medium, provided the original work is properly cited.

\begin{abstract}
Background: The aim of the present study was to evaluate the antidiabetic potential of Manomani chooranam (MMC), an indigenous polyherbal siddha formulation in Streptozotocin (STZ) induced diabetic female Wistar albino rats. Methods: Aqueous extract of MMC was prepared. Wistar albino rats were divided into six groups (n=6). Group 1 was kept as normal control, Group 2, 3, 4, 5 and 6 were induced diabetes. After induction, the group 2 was kept as diabetes control; Group 3 received the standard drug metformin $(100 \mathrm{mg} / \mathrm{kg})$, whereas Groups 4, 5 and 6 were treated with the aqueous extract of MMC at $500 \mathrm{mg} / \mathrm{kg}, 1000 \mathrm{mg} / \mathrm{kg}$ and $1250 \mathrm{mg} / \mathrm{kg}$ doses, respectively for the 21 days. Blood sugar was estimated at the end of each week. At the end of the study, rats were sacrificed and the pancreas was analyzed for histopathological changes. Data expressed as mean \pm standard error of the mean. Statistical analysis was done using one-way ANOVA followed by post hoc Tukey's test. $\mathrm{p}<0.05$ considered statistically significant.

Results: The groups which received aqueous extract of $\mathrm{MMC}$ at $500 \mathrm{mg} / \mathrm{kg}$, $1000 \mathrm{mg} / \mathrm{kg}$ and $1250 \mathrm{mg} / \mathrm{kg}$ showed a significant decrease in the mean blood sugar level when compared to normal level. The groups which received MMC shows significant reduction in blood sugar level in comparison with standard drug metformin $100 \mathrm{mg} / \mathrm{kg}$.

Conclusions: The aqueous extract of MMC was able to decrease the elevated blood sugar levels in dose dependent manner.
\end{abstract}

Keywords: Diabetes mellitus, Manomani chooranam, Aqueous extract, Streptozotocin

\section{INTRODUCTION}

Diabetes mellitus is one of the metabolic syndromes, which is characterized by hyperglycaemia, hyperuricemia, hyperaminoacidemia and it leads to hypoinsulinemia and reduced action of insulin. ${ }^{1}$ The global prevalence of diabetes is estimated to increase from $4 \%$ in 1995 to $5.4 \%$ by the year of $2025 .^{2}$ Most of the antidiabetic drugs such as sulfonylureas, biguanides, $\alpha$-glucosidase inhibitors, incretin-mimetic etc., have some kind of adverse effects like nausea, vomiting, diarrhoea, abdominal pain, headache, etc. Thus search for a new safe and potent anti-diabetic herbal formulation drug is essential to overcome these problems. Asper world ethno botanical reports nearly 1000 plants could be used to treat diabetes mellitus. In siddha medicine, many single and polyherbal formulations and higher medicine like chooranam, parpam, chendooram and chunam have been practised cure or control diabetes mellitus from time immemorial. $^{3}$

Manomani chooranam (MMC), a polyherbal siddha formulation containing nineteen ingredients of herbal origin, which is used in traditional medicine to treat type 
II diabetes, contains both antidiabetic and antioxidant principles. Justicia adatoda, Solanum trilobatum, Ocimum sanctum, Andrographis paniculata, Aristolochia bracteolata, Azadirachta indica, Murraya koenigii, Eclipta prostrate, Evolvulusal sinoides, Terminalia chebula, Phyllanthus emblica, Zingiber officinale, Piper longum, Elettaria cardamomum, Cuminium cyminum, Alangium salvifolium, Ficus religiosa, Ficus racemosa, Withania somnifera. ${ }^{4-21}$ Cassia auriculata are rich in bioflavonoids helps in metabolic disorders and has antipyretic, hepatoprotective, antidiabetic, antiperoxidative, hypolipidemic and microbicidal activity. ${ }^{22}$ Phyllanthus amarus, Terminalia belerica, Piper nigrum, Ficus bengalensis also have hypolipidaemic activity. ${ }^{23-26}$ These formulations help treating diabetic patients as a hypoglycemic and antioxidant agent with fewer side effects. But there is no substantial evidence to prove its efficacy in-vivo.

\section{METHODS}

\section{Drug and chemicals}

Manomani chooranam was procured from Dr. Iyyankannu, Head and Professor, Department of Sirappu Maruthuvam, Maria Siddha Medical College, Thiruvattaru, Kanyakumari (D.t), India. Streptozotocin was purchased from sigma chemicals, Mumbai. Metformin was procured from MGMC Pharmacy store.

\section{Ethical clearance}

The study was one after being approved by Institutional Animal Ethics Committee (Ref. No.06/IAEC/MG/20171). Adult female Wistar albino rats (weighing 150-200g) were used for acute toxicity and anti-diabetic activity. The animals were purchased from TANUVAS, Chennai. They were kept individually in cages, fed with standard pellet and water; animals were maintained at a temperature of $27 \pm 3^{0} \mathrm{C}$.

\section{Preparation of MMC aqueous extract}

As per Siddha Pharmacopeia, MMC was taken by boiling $100 \mathrm{gm}$ of chooranam with $400 \mathrm{ml}$ of water by boiling in slow flame and then filtered. The aqueous extract prepared is stored in an airtight container.

\section{Acute toxicity study}

As per OECD 423 guidelines, MMC aqueous extract was administered through oral gavage to female Wistar rats $(\mathrm{n}=3)$ in a dose of $2000 \mathrm{mg} / \mathrm{kg}$ body weight. The rats were observed for the first 24 hours for any signs and symptoms of toxicity or death and later for 2 weeks. The procedure was repeated with higher doses of MMC $5000 \mathrm{mg} / \mathrm{kg}$ body weight using 3 female Wistar albino rats

\section{Dose selection}

As the limit dose did not exhibit any signs of toxicity, a dose of $2000 \mathrm{mg} / \mathrm{kg}$ body weight p.o., was taken as dose for the main study. Metformin at a dose of $100 \mathrm{mg} / \mathrm{kg}$ was taken as a standard control.

\section{Induction of diabetes in Wistar albino rats}

The overnight fasted Wistar albino rats were injected with intraperitoneal (i.p.). Inj. streptozotocin in $0.1 \mathrm{M}$ cold sodium citrate buffer, at the dose of $35 \mathrm{mg} / \mathrm{kg}$ body weight. To counter-act the drug-induced hypoglycemia, the rats were subjected to drink $5 \%$ glucose solution overnight. A week time was given for the development of diabetes. The confirmation of hyperglycemia was determined by monitoring blood glucose level more than $200 \mathrm{mg} / \mathrm{dl}$ were considered as diabetic induced rats. Then the animals were divided into the respective groups (6 animals in each group)

Six groups with six rats in each (a total of 36 rats) were used. All groups received respective drugs for 3 weeks.

Group I (control) received normal saline P.O (per orally). Group II (negative control) diabetic Induced rats received normal saline without treatment. Group III (positive control) diabetic induced rats received metformin P.O $100 \mathrm{mg} / \mathrm{kg}$ body weight once a day for 3 weeks. Group IV, V and VI treatment group (low, moderate and high dose) received $500 \mathrm{mg}, 1000 \mathrm{mg}, 1250 \mathrm{mg} / \mathrm{kg}$ of the chooranam extract respectively once a day P.O (Table 1).

Table 1: Experimental design of MMCAE.

\begin{tabular}{|lll|}
\hline Groups & Purpose & Treatment \\
\hline Group I & Normal control & Standard pellet feed with normal saline \\
\hline Group II & Negative control & Standard pellet feed with normal saline \\
\hline Group III & Positive control & Standard pellet feed with metformin $100 \mathrm{mg} / \mathrm{kg}$ \\
\hline Group IV & Low dose & Standard pellet feed $+500 \mathrm{mg} / \mathrm{kg}$ of $\mathrm{MMCAE}$ \\
\hline Group V & Moderate dose & Standard pellet feed $+1000 \mathrm{mg} / \mathrm{kg}$ of MMCAE \\
\hline Group VI & High dose & Standard pellet feed $+1250 \mathrm{mg} / \mathrm{kg}$ of MMCAE \\
\hline
\end{tabular}

MMCAE- MMC aqueous extract. 
The blood samples were collected from rat tail vein at the time intervals on $0,7^{\text {th }}, 14^{\text {th }}$ and $21^{\text {st }}$ days to estimate the blood glucose level by Tail snipping method. At the end of the $21^{\text {st }}$ days, animals were sacrificed with I.M Injection sodium thiopentone and diffuse pancreas were collected from all 36 animals and subjected to histopathological study. Rat pancreas was collected and fixed in $10 \%$ formaldehyde solution for microscopic examination using haematoxylin-eosin stain.

\section{Statistical analysis}

Collected data were entered in Microsoft excel 2019 and analyzed using JASP 0.8 .4 .0 version. Results were expressed in mean \pm standard error of the mean as a table. Statistical analysis was performed using one way ANOVA followed by post hoc Tukey's test. The $\mathrm{p}<0.05$ was considered statistically significant.

\section{RESULTS}

\section{Acute toxicity study of Manomani chooranam aqueous extract (MMCAE) in rats}

Acute toxicity studies confirmed that the MMCAE up to a dose of $5000 \mathrm{mg} / \mathrm{kg}$ body weight was non-toxic. There was no mortality or any abnormal behavioral changes were found at any of the selected doses the end of the study.

Table 2: Effect of MMC aqueous extract formulation on fasting blood glucose levels in STZ induced diabetic rats.

\begin{tabular}{|c|c|c|c|c|}
\hline \multirow[t]{2}{*}{ Treatment } & \multicolumn{4}{|c|}{ Blood glucose level in mg/dl } \\
\hline & $0^{\text {th }}$ day & $7^{\text {th }}$ day & $14^{\text {th }}$ day & $21^{\text {st }}$ day \\
\hline Normal control & $115 \pm 5.76$ & $106.6 \pm 5.75$ & $103 \pm 3.95$ & $101 \pm 1.67$ \\
\hline Diabetic control & $215.8 \pm 11.14$ & $207.6 \pm 9.83$ & $204.3 \pm 4.97$ & $192.3 \pm 7.31$ \\
\hline Positive control (metformin) & $218.5 \pm 5.96$ & $184.3 \pm 3.01$ & $161.3 \pm 4.18$ & $137.2 \pm 2.64$ \\
\hline MMCAE- low dose & $223.5 \pm 2.88$ & $121.2 \pm 2.64 * *$ & $111.5 \pm 3.83 * *$ & $102.2 \pm 2.32 * *$ \\
\hline MMCAE- moderate dose & $220.2 \pm 3.76$ & $125.5 \pm 2.43 * *$ & $118.2 \pm 5.49 * *$ & $111 \pm 3.46^{* *}$ \\
\hline MMCAE-high dose & $214.7 \pm 3.98$ & $140.5 \pm 4.76^{* *}$ & $131.5 \pm 3.73 * *$ & $124.7 \pm 2.42 * *$ \\
\hline
\end{tabular}

MMC values are expressed as mean \pm SD $(n=6)$. ${ }^{*} \mathrm{p}<0.05$ when compare to positive control group; **p<0.01 when compared to positive control group (one-way ANOVA followed by a post host Tukey's test) STZ-streptozotocin.

\section{Effect of MMC on blood glucose level}

The blood glucose levels were significantly increased after STZ injection, when compared to that of normal control group and the animals were grouped according to the blood glucose levels. The groups which received low dose $(500 \mathrm{mg} / \mathrm{kg})$, moderate dose $(1000 \mathrm{mg} / \mathrm{kg})$ and high dose $(1250 \mathrm{mg} / \mathrm{kg})$ showed significant reduction in blood sugar level. The blood glucose levels were significantly reduced in all treatment groups under study when compared to positive control (Figure 1) and (Table 2).

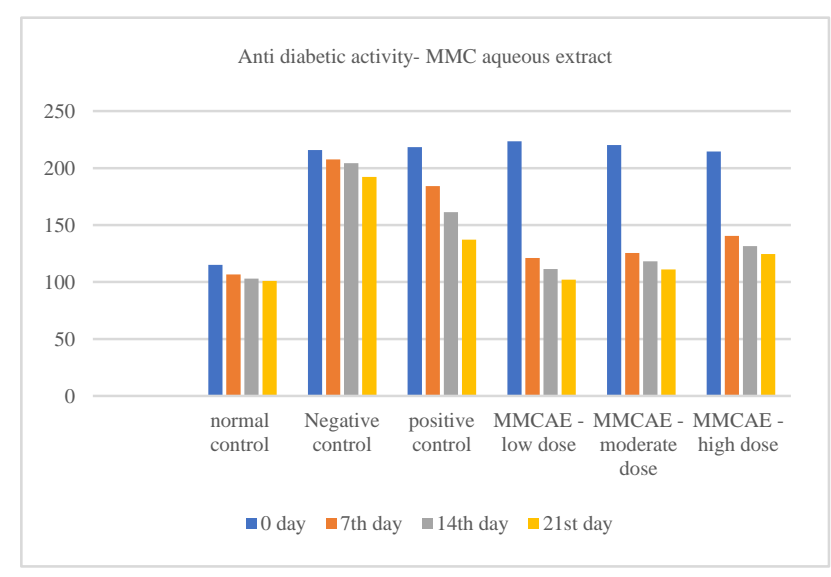

Figure 1: Effect of MMC aqueous extract formulation on fasting blood glucose levels (mg/dl) in STZ induced diabetic rats.

\section{Histopathological study of pancreas}

All the sections of normal control (Figure 2A) showed normal tissue architecture with lobules separated by connective tissue septae. The lobules consist of exocrine acinar cells.

The endocrine islets of Langerhans were embedded within the acinar cells. All the sections of disease control (Figure 2B) showed highly reduced islets number. The number of cells in each islets and the size of islets were also reduced.

The tissue sections of positive control metformin (Figure 2C), low dose of MMMCAE (Figure 2D), moderate dose of MMCAE (Figure 2E), high dose of MMCAE (Figure $2 \mathrm{~F}$ ) has shown an increase in size of the islets compared to NC group.

There was an increase in size of cells in each group compared to negative control group compared to normal control.

There was no loss of tissue architecture and necrosis in any of the group. There was protection in all three treated groups which was evident by the increase in size of islets of Langerhans and there was no difference in protection of cells in these groups. 

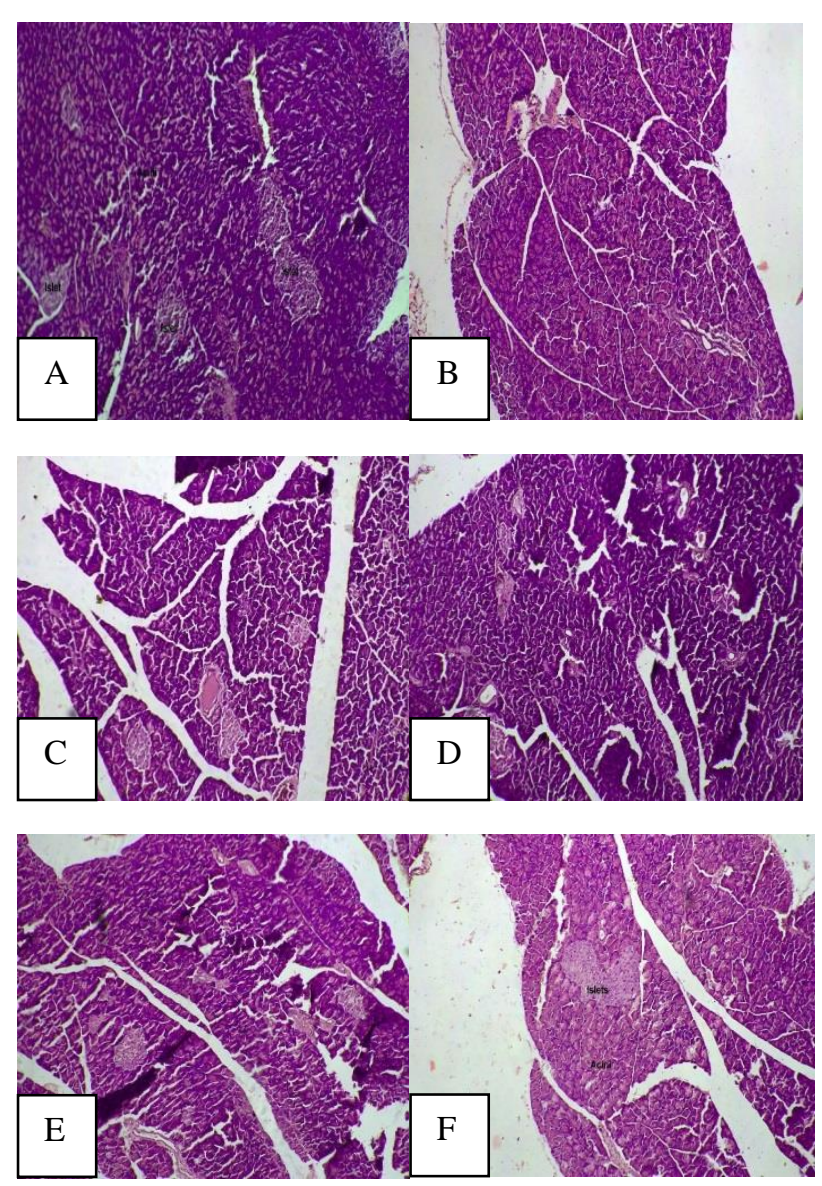

Figure 2: (A) Normal pancreas control group10xshowing normal; (B) negative control 10x showing reduced no of islets cells; $(C)$ positive control (metformin) 10x- increase in size of islets cells; (D) MMC aqueous extract low dose 10x-increase in size of islets cells; ( $\mathrm{E}) \mathrm{MMC}$ aqueous extract moderate dose 10x- increase in size of islets cells; (F) MMC aqueous extract high dose $10 \mathrm{x}$ - increase in size of islets cells.

\section{DISCUSSION}

Diabetes has become a major health problem in most of the countries. Combination of herbs has been extensively used from ancient times and had shown potent antidiabetic activities without toxicity. Therefore a polyherbal formulation was prepared. ${ }^{28}$ Since STZ has selective pancreatic islet beta cell cytotoxicity it is used to induce type I diabetes in rat model. ${ }^{29}$ Streptozotocin enters the $B$ cell causing alkylation of DNA resulting in necrosis.

In the present study, the anti-diabetic activity of MMC aqueous extract was investigated in STZ induced diabetes in rat models. The 3-week study was conducted in the Central Animal house, Mahatma Gandhi Medical College and Research Institute, Puducherry. In our study, the MMCAE at three doses, that is, $500 \mathrm{mg} / \mathrm{kg}, 1000 \mathrm{mg} / \mathrm{kg}$, and $1250 \mathrm{mg} / \mathrm{kg}$ produced a dose-dependent reduction in the sugar levels especially in first week of treatment when compared to the standard drug metformin (100 $\mathrm{mg} / \mathrm{kg}$ ), which is followed by significant reduction in sugar levels in subsequent weeks till our study (3 weeks).

The poly herbal formulation significantly reduced the blood glucose level in streptozotocin-induced-diabetic rats as compared to the diabetic control group. The possible mechanism by which polyherbal formulation brings about its hypoglycaemic action in diabetic rat may be by potentiating the insulin effect of plasma by increasing either the pancreatic secretion of insulin from the existing beta cells or by its release from the bound form. $^{27}$

Lack of insulin leads to inactivation of the glycogen synthase systems. ${ }^{30}$ The possible mechanism of lowering blood glucose level by herbal formulation TAB may be by inhibiting the pancreatic enzymes resulting in an increase in pancreatic secretion of insulin or its release from bound form. ${ }^{28}$

\section{CONCLUSION}

The results show that Manomani chooranam is safe and is able to control the blood sugar levels. The ability to reduce the blood sugar levels is due to the presence of active ingredients in this poly herbal formulation. Hence it can be a potent anti-diabetic drug for usage, which needs further evaluation.

\section{ACKNOWLEDGEMENTS}

Authors would like to thank authorities of Department of Pharmacology, MGMCRI and A.T.S.V.S. Siddha Medical College and Research Institute, Munchirai, Marthandam, K. K. District for support during this study.

Funding: No funding sources

Conflict of interest: None declared

Ethical approval: The study was approved by the Institutional Ethics Committee

\section{REFERENCES}

1. Lekhana AR, Palaksha MN, Gnanasekaran D, SenthiKumar GP, Tamizmani T. Medicinal plants potential to treat Diabetes: A Review. World J Pharma Res. 2018;7(19):492-503.

2. Jarald E, Joshi SB, Jani DC. Diabetes and herbal medicines. Iran J Pharmacol Therap. 2008;7:97-106.

3. Patel P, Harde P, Pillai P, Darji N, Patel B. An Intl Res J Anti-diab Herb Drugs. A review available online at review articles Pharmacophore. 2013;3:1829.

4. Gulfraz M, Ahmad A, Asab M J, Sadiq A, Afzal U, Imarn M, et al. Antidiabetic activities of leaves and root extracts of Justicia Adhatoda (Linn) against alloxan induced diabetes in rats. Afr $\mathrm{J}$ Biotech. 2011;10(32):6101-6.

5. Doss A, Palaniswamy M, Angayarkanni J, Dhanabalan R. Antidiabetic activity of water extract 
of Solanum trilobatum (Linn) in alloxan induced diabetes in rats. Afr J Biotech. 2009;8:5562-64.

6. Hannan JMA, Marenah L, Ali L, Rokeya B, Flatt PR. Ocimum sanctum leaf extracts stimulate insulin secretion from perfused pancreas, isolated islets and clonal pancretic beta cells. J Endocrinol. 2006;189:172-36.

7. Premanath R, Nanjaiah L. Antidiabetic and antioxidant potential of Andrographis paniculata Nees. Leaf ethanol extract in streptoztocin induced diabetic rats. J Appl Pharm Sci. 2015;5(01):069-76.

8. Thangavelu K, Doss VA. Antidiabetic effect of $50 \%$ hydro ethanolic extract of Aristolochia bracteolata (Linn) Leaves in streptoztocin induced diabetic rats. World J Pharm Res. 4(2):819-32.

9. Khosla P, Bhanwra S, Singh J, Seth S, Srivastava RK. A study of hypoglycemic effects of Azadirachta indica (Neem) in normal and alloxan diabetic rabbits. Indian J Pharmacol. 2000;44(1):69-74.

10. Kumar DB, Mitra A, Mahadevappa M. Antidiabetic and hypolipidemic effects of Mahanimbine (Carbazole alkaloid) from Murraya Koenigii leaves. Int J Phytomed. 2010;2:22-30.

11. Rahman MS, Rahman MZ, Begum B, Chowdhury R, Islam SKN, Rashid MA. Antidiabetic principle from Eclipta prostrata. Lat Am Pharma. 2011;30(8):165060.

12. Gomathi D, Ravikumar G, Kalaiselvi M, Devaki K, Uma C. Efficacy of Evolvulus alsionoides (L.) L. on insulin and antioxidants activity in pancreas of streptozotocin induced diabetic rats. J Diab Metab Disorder. 2013;12(1):39.

13. Kumar SGP, Arulselvan P, Kumar SD, Subramanian SP. Anti-diabetic activity of fruits of Terminalia chebula on streptozotocin induced diabetic rats. J Health Sci. 2006;52(3):283-91.

14. Sultana Z, Jami SI, Ali E, Begum M. Investigation of antidiabetic effect of ethanolic extract of Phyllanthus emblica Linn, fruits in experimental animal models. Pharmacol Pharm. 2014;5:11-8.

15. Adbulrazaq NB, Cho MM, Win NN, Zaman R, Rahman MT. Beneficial effects of ginger (zingiber officinale) on carbohydrate metabolism in streptozotocin-induced diabetic rats. $\mathrm{Br} \mathrm{J}$ Nutr. 2012;108:1194-201.

16. Nabi SA, Kasetti RB, Sirasanagandla S, Tilak TK, Kumar MVJ, Rao CA. Antidiabetic and antihyperlipidemic activity of Piper longum root aqueous extract in Streptozotocin induced diabetic rats. BMC Complement Alternat Med. 2013;37:1-9.

17. Bhat GMN, Nayak N, Vindoraj K, Chandralekha N, Mathai P, Cherian J. Comparison of the efficacy of cardamom (Elettaria Cardamomum) with Pioglitazone on dexamethasone-induced hepatic steatosis, dyslipidemia, and hyperglycaemia in albino rats. J Adv Pharm Technol Res. 2015;6(3):136-40.

18. Srivsatava R, Srivsatava SP, Jaiswal N, Mishra A, Maurya R, Srivsatava AK. Antidiabetic and antidyslipidemia activities of Cuminium cyminum $L$. in validated animal models. Med Chem Res. 2013;20(9).

19. Venkateshwarlu R, Raju AB, Yerragunta VG. Phytochemistry and pharmacology of Alangium salvifolium: a review. J Pharm Res. 2011;4(5):14235.

20. Khan KV, Khan MA, Ahmad M, Hussain I, Mazari $\mathrm{P}$, Fazal H, et al. Hypoglycemic potential of genus Ficus L. A review of ten years of plant based medicine used to cure diabetes. J Appl Pharm Sci. 2011;6:223-7.

21. Udaykumar R, Kasthurirengan S, Mariashibu TS, Rajesh M, Anbazhagan VR, Kim SC, et al. Hypoglycemic and hypolipidaemic effects of Withania somnifera root and leaf extracts on alloxan induced diabetic rats. Int J Mol Sci. 2009,10:236782.

22. Anandan A, Eswaran R, Doss A, Sangeetha G. Anand SP. Chemical compounds Investigation of cassia auriculate Leaves- A potential Folklore medicinal plant. Bulletin Environ Pharmacol Life Sci. 2011;1(1):20-3.

23. Umbrae RP, Mate GS, Jawalkar DV, Patil SM, Dongare SS. Quality evaluation of Phyllanthus amarus (schumach) leaves extract for its hypolipidemic activity. Biol Med. 2009;1(4):28-33.

24. Saravanan S, Srikumar R, Manikandan S, Parthasarathy NJ, Sheeladevi R. Hypolipidemic effect of tribal in experimentally induced hypercholesteremic rats. The Pharmaceutical society of Japan ; Yakugaku Zasshi. 2007;27(2):385-8.

25. Maneesai P, Scholfield CN, Chootip K. Piperine is anti-hyperlipidemic and improves endotheliumdependent vasorelaxation in rats on a high cholesterol diet. J Physiol Biomed Sci. 2012;25(1):27-30.

26. Joseph B, Raj JS. An overview-Ficus bengalensis Linn. Int J Pharma Sci Review Res. 2011;6(1):21-4.

27. Chaudhuri A, Sharma S. Evaluation of antidiabetic activity of polyherbal formulation in streptozotocin induced diabetic rats. UK $\mathrm{J}$ Pharma Biosci. 2016;4(5):1-6.

28. Saxena N, Argal A. Evaluation of antidiabetic activity of a herbal formulation. EC Pharmacol Toxicol. 2018; 6(5):349-55.

29. Gandhi R, Sasikumar P. Antidiabetic effect of Merremia emarginata Burm $F$ in streptozotocin induced diabetic rats. Asian Pac J Trop Biomed. 2012;2(4):281-6.

30. Szkudelski T. The mechanism of alloxan and streptozotocin action in B cells of the rat pancreas. Physiolog Res. 2001;50(6):537-46.

Cite this article as: Anandh SJV, Kumarappan M, Shanmuganathan P, Vinayagam S, Iyyankannu, Narayanamurthy U. Antidiabetic activity of Manomani chooranam aqueous extract on female wistar albino rats. Int J Basic Clin Pharmacol 2019;8:2153-7. 